Фармацевтичний менеджмент, маркетинг та логістика

Pharmaceutical management, marketing and logistics

Рекомендована д. фрармац. наук, профр. Б. П. Громовиком

УДК 339.13:616.85:614.272

DOI

\title{
АНАЛІЗ НОМЕНКЛАТУРИ СЕДАТИВНИХ ТА СНОДІЙНИХ ПРЕПАРАТІВ В УКРАЇНІ
}

\author{
(сО. В. Савельєва, І. М. Владимирова
}

Національний фрармацевтичний університет, Харків

\begin{abstract}
Резюме: проаналізовано асортимент сучасних седативних та снодійних препаратів, зареєстрованих в Україні. Встановлено, що фрармацевтичні підприємства України займають 76,70 \% ринку. Синтетичні препарати займають 22,33 \% ринку, препарати рослинного походження - 77,67 \%. Монопрепарати представлені препаратами валеріани, півонії та кропиви собачої. Результати щодо співвідношення форм випуску доводять, що лікарські форми у вигляді таблеток та настойки займають найбільші сегменти. Встановлено одноманітність видів лікарських рослин, що входять до складу седативних та снодійних засобів.
\end{abstract}

Ключові слова: седативні засоби, снодійні засоби, номенклатура препаратів, фрітотерапевтичні засоби.

Вступ. Захворювання нервової системи можуть виникати в результаті ряду причин, зокрема, стресові ситуації, порушення режиму дня, малоактивний спосіб життя, тривале нервове напруження тощо. Все це призводить до порушень сну, постійного головного болю, хронічної втоми. Захворювання нервової системи проявляються порушенням рівноваги при ходьбі і порушеннями координації рухів, утрудненою орієнтацією в просторі, зниженням пам'яті, нападами, слабкістю, при тяжких порушеннях роботи нервової системи - паралічами $[1,2]$.

Більшість дорослого населення планети страждає через порушення з боку нервової системи. Найчастіше спосіб життя, пов'язаний з розмаїттям стресових факторів, і $є$ основною причиною більшості нервових розладів. Захворювання нервової системи здатні приймати різну форму - від головного болю до нападів епілепсії. Але повністю виключити стреси зі свого життя практично не можливо. Максимум що можна зробити - це звести їх кількість і вираженістть до мінімуму. Тому в даному випадку важливим $€$ профрілактика виникнення порушень роботи нервової системи та їх раціональна терапія. Для цього застосовуються препарати 3 нейромедіаторною дією, що мають комплексний вплив на етіологічні фрактори, патогенетичні ланки та симптоматичні прояви захворювання [2, 6, 9, 13].

Методи дослідження. Дослідження проводились за допомогою загальноприйнятих статистичних і маркетингових досліджень електронних і паперових джерел інфрормації. Об'єктом роботи була інформація про седативні та снодійні препарати, зареєстровані в Україні.

Результати й обговорення. 3 метою дослідження частки рослиннихседативнихтаснодійнихпрепаратів, зареєстрованих в Україні, та аналізу видів лікарських рослин, що входять до їх складу, досліджено номенклатуру регіонального ринку даної групи препаратів. Відповідно до класифрікаційної системи ATC [3], препарати даного сегменту представлені групами: комбіновані препарати барбітуратів; засоби, близькі до бензодіазепіну; агоністи рецепторів мелатоніну, препарати бромідів та дексмедетомідину та група інших седативних та снодійних препаратів. До останньої групи входять препарати на основі валеріани, півонії, кропиви собачої та комбіновані рослинні препарати.

Аналізуючи частку кожної країни-виробника, представленої на вітчизняному фрармацевтичному ринку, встановлено, що продукція даного сегменту (седативних та снодійних засобів) фрармацевтичних підприємств України займає 76,70 \%; Німеччини 6,80\%; Польщі-2,91\%; США, Чехії, Словенії, Франції - по 1,94 \%; Латвії, Туреччини, Канади, Угорщини, Фінляндії, Білорусі - по 0,97 \% (рис. 1).

Препарати даної групи представлені твердими (таблетки, капсули, гранули) та рідкими (настойка, краплі, екстракт рідкий, розчин оральний, концентрат розчину для інфрузій) лікарськими формами, а також у вигляді збору ЛРС у пачці та індивідуальних фрільтр-пакетах. На рисунку 2 наведено результати проведеного порівняльного аналізу. Серед представлених лікарських фрорм переважають тверді форми $(58,4 \%)$, найбільший відсотковий вміст мають таблетки (33,63 \%). Найбільшу частку ринку рідких лікарських фрорм займають настойки $(19,47$ \%). Низькою часткою характеризуються такі форми, як екстракт рідкий та розчин оральний (по $1,77 \%)$.

Аналізуючи стан фрармацевтичного ринку України седативних та снодійних препаратів за походженням, встановлено, що синтетичні препарати займають 22,33 \% ринку, препарати рослинного походження $77,67 \%$ (рис. 3 ).

ISSN 2312-0967. Фармацевтичний часопис. 2015. № 3 
Фармацевтичний менеджмент, маркетинг та логістика

Pharmaceutical management, marketing and logistics

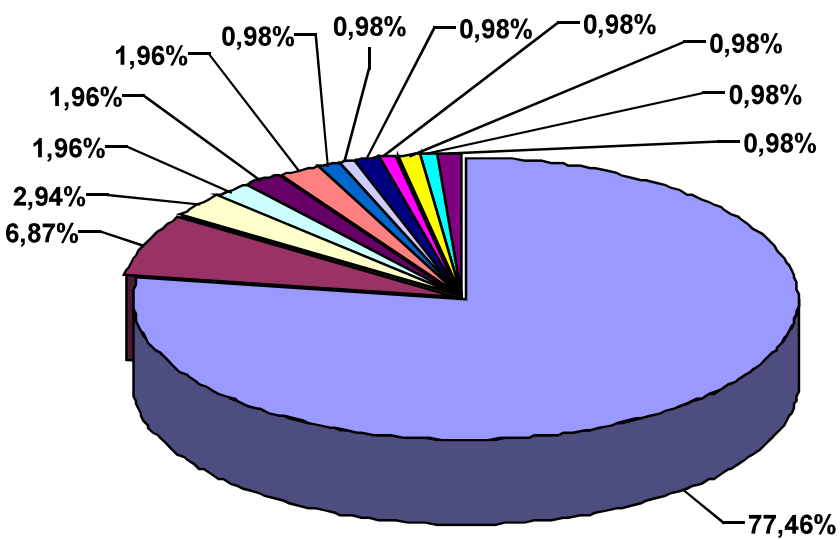

\begin{tabular}{|ll}
\hline$\square$ Україна & $\square$ Німеччина \\
$\square$ Польща & $\square$ США \\
$\square$ Чехія & $\square$ Словенія \\
$\square$ Туреччина & $\square$ Франція \\
$\square$ Латвія & $\square$ Канада \\
$\square$ Угорщина & $\square$ Фінляндія \\
$\square$ Білорусь &
\end{tabular}

Рис. 1. Порівняльна гістограма фрармацевтичних підприємств країн-виробників седативних та снодійних препаратів.

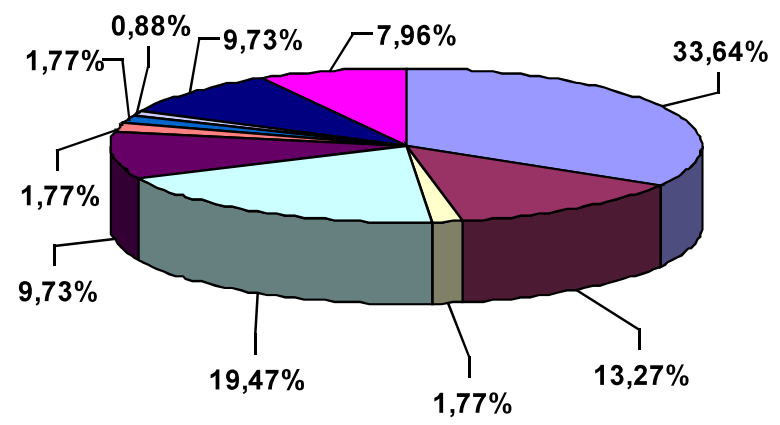

\begin{tabular}{|l|}
\hline$\square$ таблетки \\
$\square$ капсули \\
$\square$ гранули \\
口 настойка \\
$\square$ краплі \\
口 екстракт рідкий \\
$\square$ розчин оральний \\
$\square$ концентрат розчину для інфузій \\
$\square$ ЛРС пачка \\
$\square$ ЛРС фільтр-пакети \\
\hline
\end{tabular}

Рис. 2. Порівняльна гістограма лікарських фрорм седативних та снодійних препаратів.

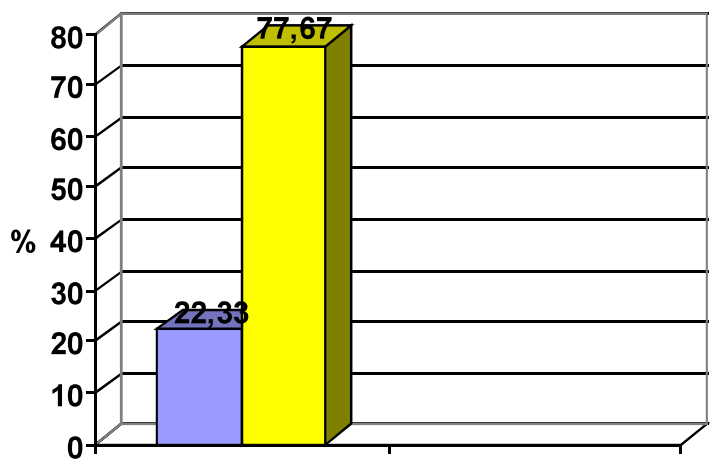

\begin{tabular}{|c|}
\hline$\square$ синтетичні \\
препарати \\
$\square$ рослинні \\
препарати \\
\hline
\end{tabular}

Рис. 3. Порівняльна гістограма седативних та снодійних препаратів за походженням.

Синтетичні препарати представлені групами комбінованих препаратів барбітуратів та засобами, близькими до бензодіазепіну. Барбітурати мають ряд недоліків. Сон, викликаний барбітуратами, відрізняється від природного: вони полегшують настання сну (засипання), але змінюють його структуру - співвідношення фраз швидкого (парадоксального, десинхронізованого) і повільного (ортодоксального, синхронізованого) сну. Нерідко сон стає переривчастим, з великою кількістю сновидінь, кошмарів. Після нього залишається тривала сонливість, розбитість, порушення координації рухів та інші небажані явища. При багатократному використанні розвивається толерантність (звикання), і для отримання снодійного ефекту необхідно збільшувати дозу. Великі дози барбітуратів та бензодіазепіну можуть пригнічувати дихання, знижувати артеріальний тиск (аж до судинного колапсу), знижувати температуру тіла, зменшувати діурез та ін. [3].

ISSN 2312-0967. Pharmaceutical review. 2015. № 3 
Фармацевтичний менеджмент, маркетинг та логістика Pharmaceutical management, marketing and logistics

Препарати рослинного походження можна розділити на дві групи - монопрепарати та комбіновані рослинні препарати. Монопрепарати представлені препаратами валеріани, півонії та кропиви собачої (рис. 4). Слід зазначити і одноманітність лікарських орорм для цієї групи.

Монопрепарати півонії та кропиви собачої представлені лише настойкою (4 та 8 препаратів відповідно) та ЛРС кропиви собачої пачка/фрільтр пакети - 3 препарати. Проте дані види лікарських рослин входять до складу багатокомпонентних лікарських засобів седативної дії, тому широко застосовуються в даному напрямку.

Різноманітністю лікарських фрорм характеризувались лише препарати валеріани: настойка (8 препаратів), таблетки (4 препарати), капсули (2 препарати), рідкий екстракт (1 препарат), ЛРС пачка/фрільтр пакети (4 препарати).

Характеризуючи вплив препаратів валеріани, півонії та кропиви собачої на фуункціональну активність ЦНС, слід вказати на деякі відмінності їх дії, зокрема, спектр дії валеріани характеризується, з одного боку, різноманітністю фрармакологічних ефектів, а 3 іншого - необхідністю певного часу для їх реалізації $[10,11]$.

У ряді випадків терапія монопрепаратами валеріани виявляється недостатньо ефективною з точки зору усунення проявів супутньої вегето-судинної дистонії, а іноді необхідне посилення седативного або снодійного есректу. 3 цією метою до валеріани у складі комбінованих препаратів додають такі лікарські рослини, як хміль звичайний, м'ята перцева, вахта трилиста, меліса лікарська, пасифлора тощо [5, 7, 8, 12].

Препарати півонії та кропиви собачої застосовують при комплексному лікуванні вегето-судинної дистонії, безсонні, що має невротичний характер, неврозів, епілепсії, гормональних розладах під час клімаксу, а також для боротьби з хронічним алкоголізмом [4, 5, 13].

Таким чином, при застосуванні фрітотерапевтичних засобів для есрективної терапії важливим є врахування їх механізму дії і особливостей фрармакологічної дії на організм людини.

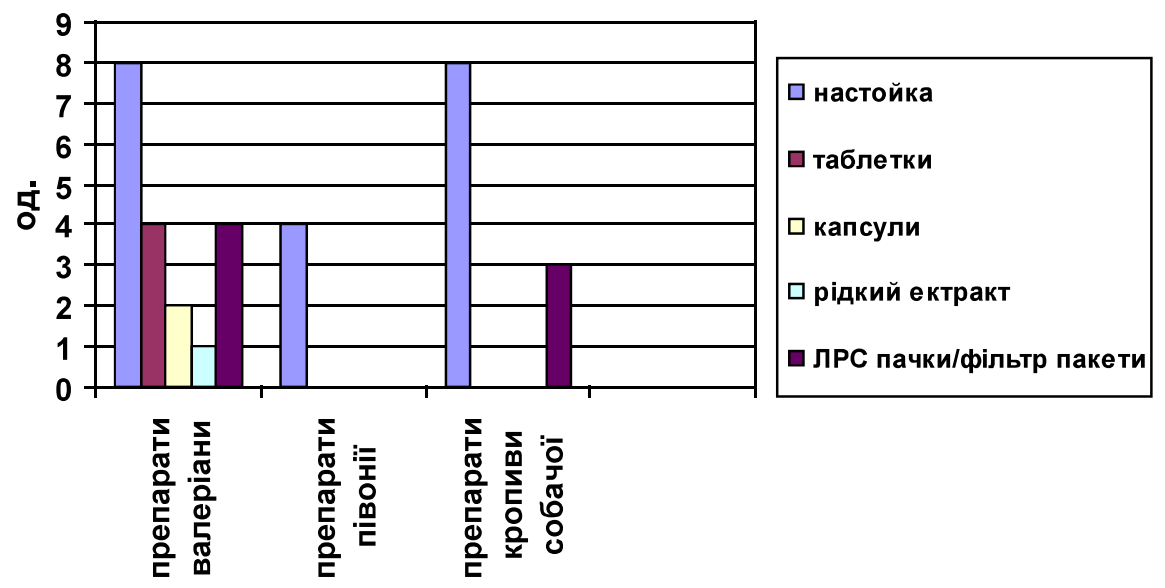

Рис. 4. Порівняльна гістограма лікарських фрорм монокомпонентних рослинних препаратів.

Висновки. 1. Аналізуючи частку кожної країнивиробника, представленої на вітчизняному фрармацевтичному ринку, встановлено, що продукція сегменту ринку седативних та снодійних засобів фрармацевтичних підприємств України займає 76,70\%.

2. Аналізуючи стан фрармацевтичного ринку України седативних та снодійних препаратів за походженням встановлено, що синтетичні препарати займають 22,33 \% ринку, препарати рослинного походження -
77,67 \%. Монопрепарати представлені препаратами валеріани, півонії та кропиви собачої. Слід зазначити і одноманітність лікарських фрорм для цієї групи.

3. Аналізуючи види лікарських рослин, що входять до складу седативних та снодійних засобів, встановлено їх одноманітність. Перспективним в цьому напрямку може бути пошук інших видів лікарської рослинної сировини нейромедіаторної дії як джерел для створення фрітотерапевтичних засобів.

\section{Список літератури}

1. Воробьева О. В. Психовегетативный синдром, ассоциированный с тревогой (вопросы диагностики и терапии) / О. В. Воробьева // РМЖ. - 2006. - Т. 14, № 23. - C. 1696-1699.

2. Карвасарский Б. Д. Неврозы / Б. Д. Карвасарский. М. : Медицина, 1990. - 574 с.

3. Компендиум. Лекарственные препараты on-line: специализированное медицинское интернет-издание для врачей, провизоров, фрармацевтов, студентов медицинских и фрармацевтических вузов [Електронный ресурс] // Режим доступу: http://compendium.com.ua.

4. Пилягина Г. Я. Лечение невротических расстройств

ISSN 2312-0967. Фармацевтичний часопис. 2015. № 3 
Фармацевтичний менеджмент, маркетинг та логістика Pharmaceutical management, marketing and logistics

с помощью ффитопрепаратов / Г. Я. Пилягина // Фитопрепараты в Украине. - 2000. - № 3-4. - С. 19-21. 5. Ушкалова А. В. Эффрективность и безопасность антидепресивных и седативных средств растительного происхождения / А. В. Ушкалова, Т. С. Илларионова // Фарматека. - 2007. - № 20. - С. 10-14.

6. Heinz K. Stress-induced functional cardiovascular pathology / K. Heinz // J. Funct. Neurol. Pathol. - 2003. Vol. 8. - P. 198-209.

7. Hohmann J. Protective effects of the aerial parts of Salvia officinalis, Melissa officinalis and Lavandula angustifolia and their constituents against enzyme-dependent and enzymeindependent lipid peroxidation / J. Hohmann // Planta Med. - 1999. - № 65. - P. 576-578.

8. Kennedy D. O. Attenuation of laboratory-induced stress in humans after acute administration of Melissa officinalis (Lemon Balm) / D. O. Kennedy [et al.] //
Psychosom. Med. - 2004. - Vol. 66, № 4. - P. 607-613.

9. Kertner D. K. Psychosomatic Medicine. - Chicago: Chicago Univ. Press, 2005. - 346 p.

10. Khom S. Valerenic acid potentiates and inhibits GABA(A) receptors: Molecular mechanism and subunit / S. Khom // Neuropharmacology. - 2007. - № 34. -P. 45-49.

11. Valeriana officinalis root extracts have potent anxiolytic effect in laboratory rats / K. Murphy, Z. J. Kubin, J. N. Shepherd, R. H. Ettinger // Phytomedicine International Journal of Phytotherapy and Phytopharmacology. - 2010. № 17. - P. 674-678.

12. Pereira P. Neurobehavioral and genotoxic aspects of rosmarinic acid / P. Pereira // Pharmacol. Res. - 2005. Vol. 52, № 3. - P. 199-203.

13. Samuelsson G. Drugs of Natural Origin. A textbook of Pharmacognosy / G. Samuelsson. - 5-th revised edition. London, 2004. - 620 p.

\title{
АНАЛИЗ НОМЕНКЛАТУРЫ СЕДАТИВНЫХ И СНОТВОРНЫХ ПРЕПАРАТОВ В УКРАИНЕ
}

\section{Е. В. Савельева, И. Н. Владимирова}

\author{
Национальный фрармачевтический университет, Харьков
}

Резюме: проанализирован ассортимент современных седативных и снотворных препаратов, зарегистрированных в Украине. Установлено, что фрармацевтические предприятия Украины занимают 76,70 \% рынка. Синтетические препараты занимают 22,33 \% рынка, препараты растительного происхождения - 77,67 \%. Монопрепараты представлены препаратами валерианы, пиона и пустырника. Результаты относительно соотношения фрорм выпуска доказывают, что лекарственные формы в виде таблеток и настойки занимают наибольшие сегменты. Установлено однообразие видов лекарственного растительного сырья, которое входит в состав седативных и снотворных средств.

Ключевые слова: седативные средства, снотворные средства, номенклатура препаратов, фритотерапевтические средства.

\section{THE ANALYSIS OF NOMENCLATURE OF SEDATIVE AND SOMNOLENT DRUGS IN UKRAINE}

\section{O. V. Savelyeva, I. M. Vladymyrova}

National University of Pharmacy, Kharkiv

Summary: the assortment of the modern sedative and somnolent drugs presented at the pharmaceutical market of Ukraine has been analyzed. It has been established that pharmaceutical manufactories of Ukraine occupy $76.70 \%$ of market. Synthetic drugs occupy $22.33 \%$ of market, plants drugs $-77.67 \%$. Monodrugs are presented by drugs of Valeriana officinales, Paeonia anomala and Leonurus cardiaca. Results in relation to correlation of producing forms prove, that medicinal forms as pills and tincture occupy the largest segments. There was established the monotony of species of medicinal plants, which are the ingridients of sedative and somnolent drugs.

Key words: sedative drugs, somnolent drugs, drugs nomenclature, phytotherapeutic drugs. 